\title{
Establishment of an extensive breeding population of a marine pulmonate snail far poleward of its previously documented range
}

\author{
Susanne Fork ${ }^{1 *}$, Bruno Pernet ${ }^{2}$ and Kerstin Wasson ${ }^{1,3}$
}

\begin{abstract}
The California salt marsh snail Melampus olivaceus, a species from southern California, has established a thriving population in the Elkhorn Slough estuary (Monterey Bay), hundreds of kilometers north of where it is longestablished and regularly found. Since the late 1800s this high littoral zone salt marsh snail has occasionally been reported in central California, but only as isolated individuals or shells. We first observed a few individuals of $M$. olivaceus in Elkhorn Slough in 2013, and the species is now abundant and reproducing throughout the estuary in Salicornia pacifica (pickleweed) marshes. We also document for the first time that this species has a planktonic, feeding larva. Salt marsh snails may have been transported northward as planktonic larvae during periodic El Niño warm water events. Such transport has been reported for other species, but what makes this case unusual is the persistence, reproduction and abundance of the snail following transport.
\end{abstract}

Keywords: Melampus olivaceus, Range shift, El Niño, Ellobiidae, Warm water anomalies, Extension, Salicornia pacifica

The California salt marsh snail Melampus olivaceus Carpenter, 1857 (hereafter salt marsh snail), is a pulmonate (air-breathing) gastropod that lives in the high littoral zone of estuaries in pickleweed (Salicornia pacifica) and other salt marsh plants (Morris et al., 1980). It is a detrivore and microalgal grazer (Page 1997; Whitcraft 2007). Like other pulmonates, members of the genus Melampus are (simultaneous) hermaphrodites (Abbott 1989); members of the few Melampus spp. whose reproductive biology has been described produce planktonic feeding veligers (e.g. M. bidentatus and M. coffea Russell-Hunter et al. 1972; Maia et al. 2012).

The historical northern range limit of M. olivaceus is somewhere to the south of Pt. Conception. Most sources list its northern range limit as Mugu Lagoon, California,

\footnotetext{
* Correspondence: skfork@gmail.com

'Elkhorn Slough National Estuarine Research Reserve, 1700 Elkhorn Road, Watsonville, CA 95076, USA

Full list of author information is available at the end of the article
}

located about $80 \mathrm{~km}$ west of Los Angeles (e.g. McLean 1978; Morris et al. 1980). Yates (1890) recorded it as abundant in Goleta Slough, about $80 \mathrm{~km}$ northeast of Mugu Lagoon, so it is possible that its historical northern range limit was actually in Santa Barbara County. $M$. olivaceus has been occasionally reported to the north of Pt. Conception, but only as isolated shells. For example, there is one record of a single empty shell of M. olivaceus found at the Salinas River mouth (Cooper 1867), about $300 \mathrm{~km}$ north of Pt. Conception, likely collected between the years 1853 and 1866. Fischer and Crosse (1870) list it as present even farther to the north, in San Francisco, citing Binney (1865) as a source. However, it is possible that the locality data they cite is incorrect, since just a few years earlier Binney stated that the northern range limit of M. olivaceus was San Diego.

The Elkhorn Slough estuary, located more than 300 $\mathrm{km}$ north along the coastline from Pt. Conception, has a long history of research on invertebrates. Various past 
studies included records of gastropods; none of these include M. olivaceus (e.g. MacGinitie 1935; Burch 1945; Smith and Gordon 1948; MacDonald 1969a; MacDonald 1969b; Fowler 1977; Nybakken et al. 1977; Carlton 1979; Fowler 1980; Morris et al. 1980; Kellogg 1985; Byers 1999; Carlton 2007; Oliver et al. 2009). Since about 2000, extensive annual surveys of salt marsh habitats have been conducted by staff of the Elkhorn Slough National Estuarine Research Reserve, and a master database of invertebrates maintained. M. olivaceus was not observed in these surveys until 2013. Thus, it seems unlikely that this salt marsh snail was present prior to 2013, at least in any numbers, or it would have been reported.

On 4 October 2013 a living Melampus olivaceus was discovered in association with pickleweed at a site in the mid-estuary on the Elkhorn Slough Reserve, during a routine survey. Another M. olivaceus shell was incidentally observed in the upper estuary several $\mathrm{km}$ upstream of the first site on 16 September 2015. Living individuals were also observed incidentally in 2016 at various sites in the estuary, though no systematic searches were undertaken for them. In 2018 (summer and fall) and 2019 (winter and summer) targeted searches for this species revealed hundreds of salt marsh snails aggregated in small groups in areas with pickleweed (at elevations from 1.5-2.0 $\mathrm{m}$ above Mean Lower Low Water), at sites ranging from the mouth of Elkhorn Slough at Moss Landing Wildlife Area upstream to the head of the estuary at Hudson Landing (Fig. 1). A few snails were found in the Old Salinas River channel (a smaller side arm connected to the main channel) but they were absent just north of the slough in pickleweed in the Pajaro River. Voucher samples were collected and archived at

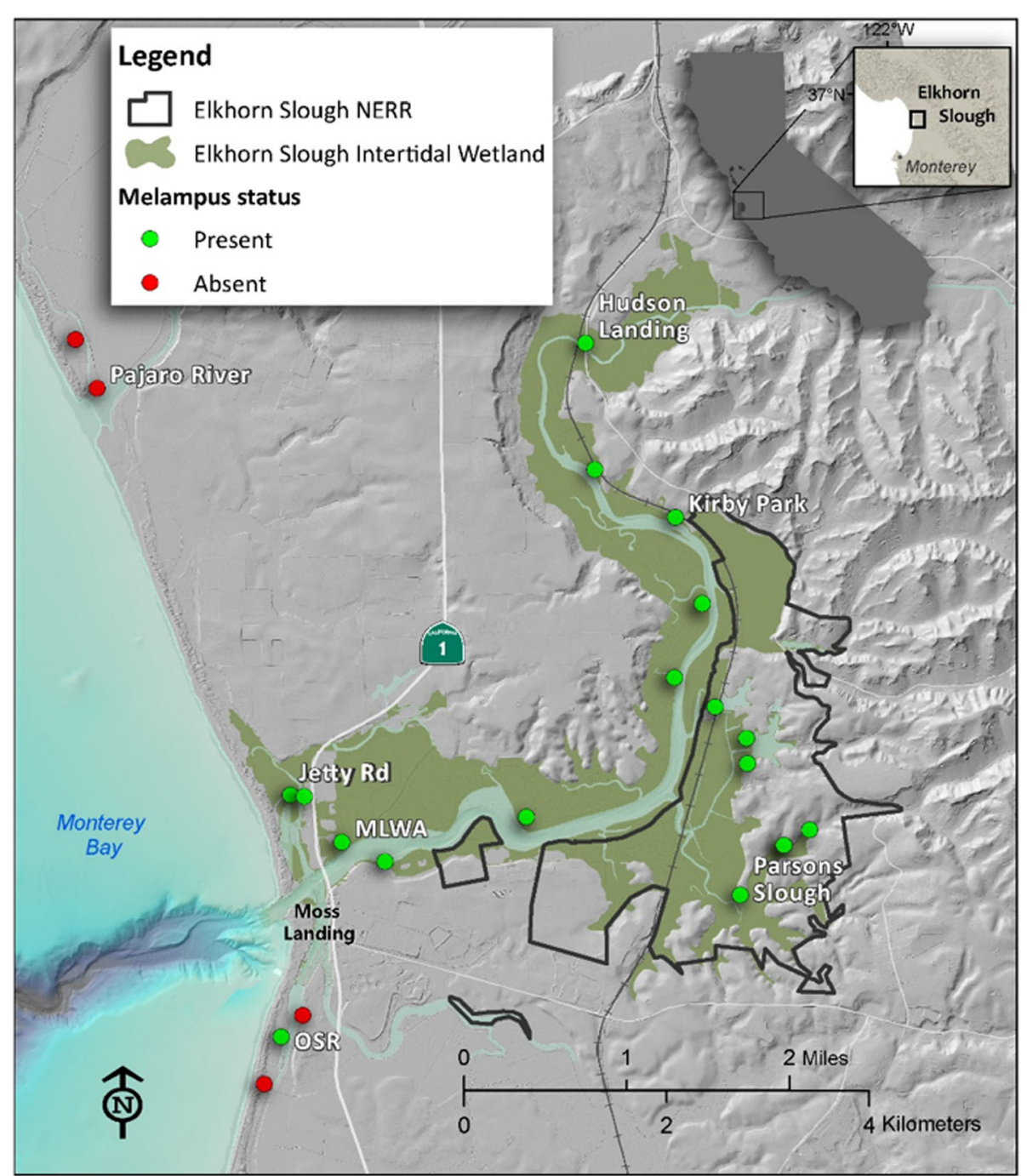

Fig. 1 Location of Melampus olivaceus at Elkhorn Slough National Estuarine Research Reserve (ESNERR) and surrounding locations. Snails present (green dot) and absent (red dot). Site abbreviations: MLWA (Moss Landing Wildlife Area); OSR (Old Salinas River Channel) 
California Academy of Sciences in San Francisco. Snails were found in small groups at the base of pickleweed, on stems, the mud below the plant, or within crab burrows (Fig. 2a, b). M. olivaceus was often found in association with another pulmonate, the non-native species Myosotella mysotis. Some salt marsh snails were found under Jaumea carnosa (marsh jaumea). Snails were found in areas of damp mud without standing water or significant thatch.

Snails observed at Elkhorn Slough in 2016-2019 were of several size classes (shell length 6-16 mm). Egg masses were observed in the field in July and August of 2018 and 2019 at many sites (Fig. 2c). Egg masses collected at several sites were observed in an aerated seawater tank. Each egg mass measured approximately 2-3 $\mathrm{mm}$ in diameter and contained greater than 100 pale yellow eggs (15 egg masses counted).

How did the snail arrive in Elkhorn Slough from locations $>300 \mathrm{~km}$ of coastline to the south? Adults certainly do not move fast enough or live long enough to make this journey unassisted. They could however have been accidentally transported by boat traffic, on field gear of researchers, or on birds' feet.

Alternatively, it seems plausible that larvae could have been transported from south of Pt. Conception to Elkhorn Slough. However, until now, nothing was known of the larval development of this species. Adults of M. olivaceus collected at Brookhurst Marsh (Huntington
Beach, southern California) in July 2013 and maintained in the laboratory on seawater-dampened paper towels deposited many egg masses. Egg mass and capsule morphology were very similar to those described for $M$. bidentatus (Russell-Hunter et al. 1972). At deposition, eggs measured $70-72.5 \mu \mathrm{m}$ in diameter, slightly smaller than the embryo size reported for M. bidentatus (Holle \& Dineen 1957). Velar cilia could clearly be seen in early veligers in capsules (Fig. 2d). Hatching of veligers was stimulated by immersion of egg masses in seawater 18 days after deposition, and swimming veligers immediately began capturing unicellular algae using opposed bands of cilia on the velar lobes (as do larvae of $M$. bidentatus: Russell-Hunter et al. 1972). We thus conclude that $M$. olivaceus has a planktonic feeding larval stage.

How long the larvae of this species remain in the plankton is unknown, but the planktonic period could last a month or more, similar to that of $M$. bidentatus (Russell-Hunter et al. 1972). When currents are running northward, larvae could be transported hundreds of kilometers poleward in a relatively short time. Indeed, Sanford et al. (2019) estimated that current anomalies and oceanographic conditions might lead to advection of larvae by about $500 \mathrm{~km}$ poleward in a month in central California. Northward transport of plankton is particularly common during El Niño events (e.g. McGowan et al. 1998). Planktonic larvae of marine benthic

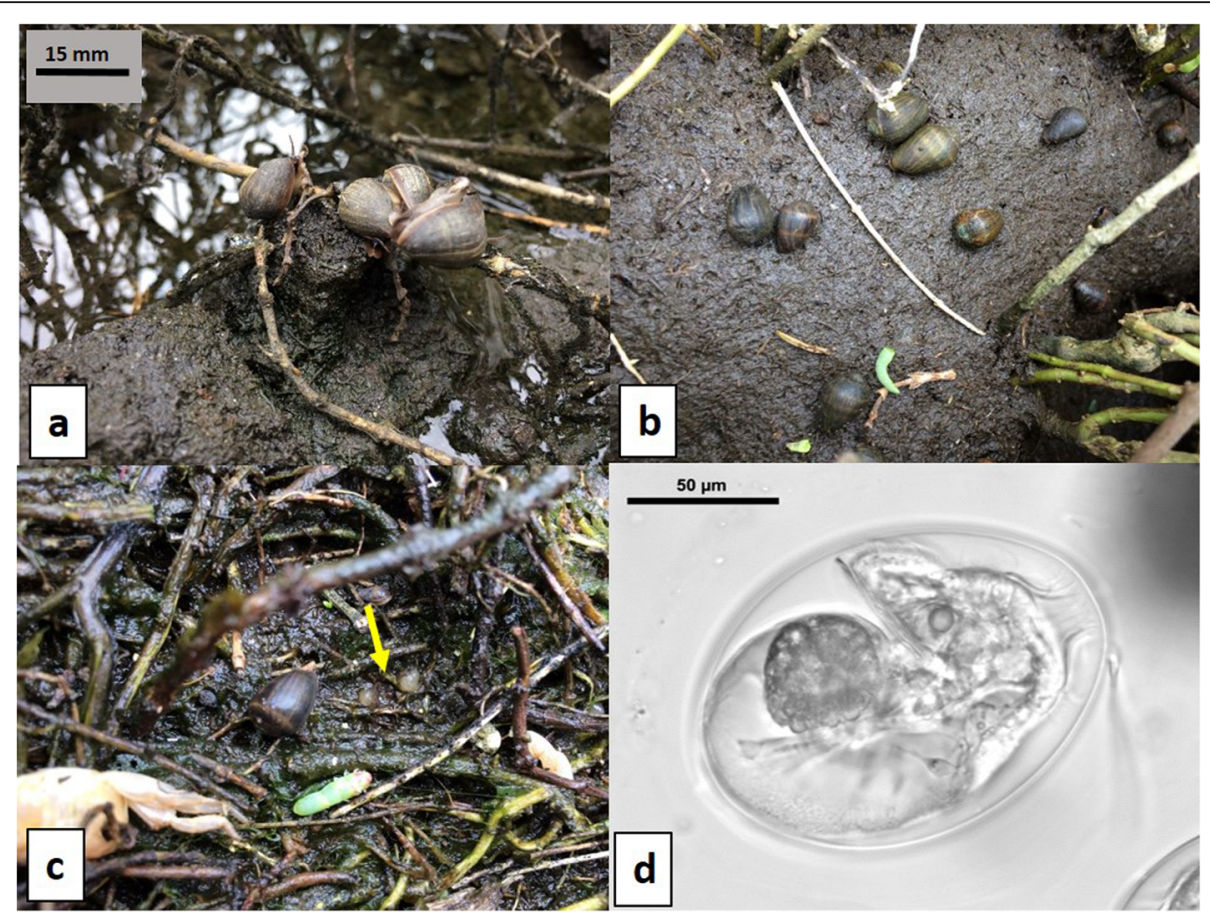

Fig. 2 Melampus olivaceus Carpenter, 1857. a and b adult snails; c two egg masses (yellow arrow), $15 \mathrm{~mm}$ scale bar for a-c; d unhatched veliger, 8 days after deposition 


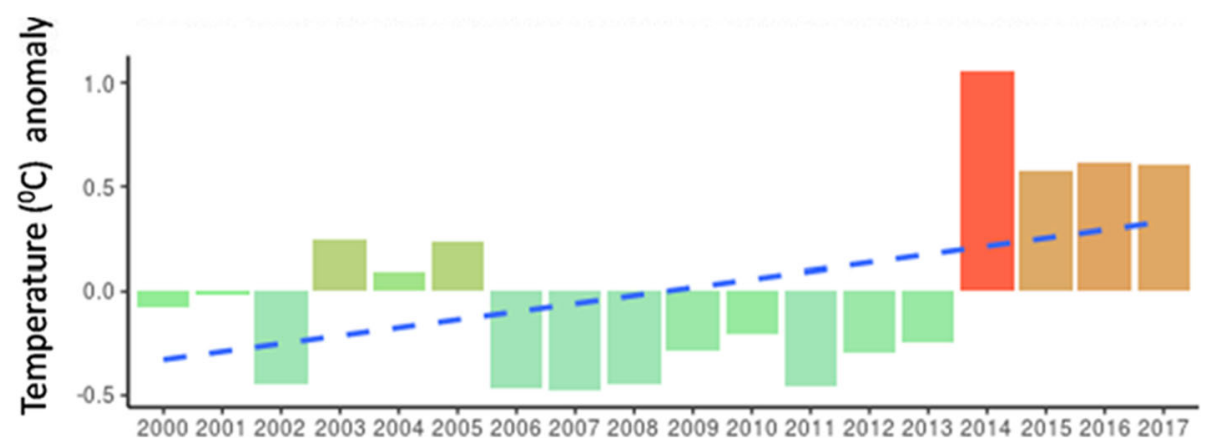

Fig. 3 Temperature sampled in South Marsh (ESNERR); annual anomalies are shown. Trend lines are shown in blue dashes. Water temperature shows a marked increase from 2000 to 2017 (Source: https://beckmw.shinyapps.io/swmp_summary/)

invertebrates can be transported poleward during atypical circulation events associated with warm water anomalies (Gaylord and Gaines 2000). During these events, increased poleward flow of the Davidson Current transports pelagic larvae northward along the eastern Pacific coast (Pearcy and Schoener 1987). The 1867 Salinas River record might have been the result of the strong El Niño of 1864 (Quinn et al. 1987), and high abundance of snails in 2018-9 could be due to transport of larvae during the strong 2015-6 El Niño. Transport of southern species northward to the Monterey Bay region and beyond is not unusual during El Niño events. For instance Lonhart et al. (2019) documented northward range extensions of 7 species (including two molluscs) along the California coast associated with warm water anomalies during 2014-2018. Sanford et al. (2019) described 37 species with northern range extensions into northern California (21of which were benthic organisms with planktonic feeding larvae). However, these range extensions are typically transient, and the transported individuals typically die before reproducing. If conditions were appropriate for these species, they would have become established long ago after earlier El Niño events.

Melampus olivaceus in Elkhorn Slough appears to provide a rare counterexample of a southern species that has persisted, and is reproducing hundreds of kilometers north of its previous range limit. The population at Elkhorn Slough is broadly distributed throughout salt marshes in the estuary, and now abundant at most of these locations. Water temperatures have remained about $0.5{ }^{\circ} \mathrm{C}$ above average since the past El Niño, perhaps allowing the snail to establish where it could not previously (Fig. 3). As climate change heats the world's oceans, such poleward range expansions will only become more common (e.g. Perry et al. 2005; Johnson et al. 2011, Yamano et al. 2011).

\section{Acknowledgements}

We wish to thank the following field biologists and experts that provided data: K. Beheshti, J. Carlton, K. Hammerstrom, C. Endris, M. Silberstein, A. Woolfolk, A. Bishop, A. Kahn, N. King, J. Parkin, J. Favaloro, G. Liermann and P.
Liermann. In addition, we thank C. Whitcraft for facilitating access to Brookhurst Marsh.

Authors' contributions

All authors collected and contributed data. SF wrote the initial manuscript. All authors contributed to the manuscript. All authors read and approved the final manuscript.

\section{Funding}

Funding for this research was provided by a grant from NOAA's Office for Coastal Management to the Elkhorn Slough Foundation on behalf of the Elkhorn Slough National Estuarine Research Reserve.

\section{Availability of data and materials}

Not applicable.

Ethics approval and consent to participate

Not applicable.

Consent for publication

Not applicable.

\section{Competing interests}

The authors declares that they have no competing interests.

\section{Author details}

${ }^{1}$ Elkhorn Slough National Estuarine Research Reserve, 1700 Elkhorn Road, Watsonville, CA 95076, USA. ${ }^{2}$ Department of Biological Sciences, California State University, Long Beach, CA, USA. ${ }^{3}$ Ecology and Evolutionary Biology, University of California, Santa Cruz, CA, USA.

Received: 11 September 2019 Accepted: 27 April 2020

Published online: 11 May 2020

\section{References}

Abbott R. Compendium of Landshells. Melbourne: American Malacologists; 1989. Binney WG. Land and fresh water shells of North America. In: Part II. Pulmonata Limnophila and Thalassophila, vol. 143. Washington: Smithsonian Miscellaneous Collections; 1865.

Burch JQ. Distributional list of the west American marine mollusks from San Diego, California to the Polar Sea: from the proceedings minutes of the Conchological Club of Southern California. Los Angeles: Conchological Club of Southern California; 1945

Byers JE. The distribution of an introduced mollusc and its role in the long-term demise of a native confamilial species. Biol Invasions. 1999:1:339-52.

Carlton J. The Light and Smith manual: intertidal invertebrates from Central California to Oregon. Berkeley: Univ of California Press; 2007.

Carlton JT. History, biogeography, and ecology of the introduced marine and estuarine invertebrates of the Pacific coast of North America. Davis: University of California Davis; 1979.

Carpenter P. Catalogue of the Reigen Collection of Mazatlan Mollusca in the British Museum. Oberlin Press; 1857. 
Cooper JG. Geographical catalogue of the mollusca found west of the Rocky Mountains: between latitudes $33^{\circ}$ and $49^{\circ}$ north, Towne \& Bacon; 1867.

Fischer, P. \& Crosse, H. 1870-1902. Études Sur les mollusques terrestres et fluviatiles du Mexique et du Guatemala Paris, Impr. impÉriale.

Fowler B. Reproductive biology of Assiminea californica (Tryon, 1865) (Mesogastropoda, Rissoacea). Veliger. 1980;23:163-6.

Fowler BH. Biology and life history of the saltmarsh snail Assiminea californica. Tryon: San Jose State University; 1977.

Gaylord B, Gaines SD. Temperature or transport range limits in marine species mediated solely by flow. Am Nat. 2000;155:769-89.

Holle PA, Dineen CF. Life-history of the salt-marsh snail, Melampus bidentatus say. Nautilus. 1957;70:90-5.

Johnson CR, Banks SC, Barrett NS, Cazassus F, Dunstan PK, Edgar GJ, et al. Climate change cascades: shifts in oceanography, species' ranges and subtidal marine community dynamics in eastern Tasmania. J Exp Mar Biol Ecol. 2011:400:17-32.

Kellogg MG. Contributions to our knowledge of Tryonia imitator (Pilsbry 1899). San Francisco: San Francisco State University; 1985.

Lonhart SI, Jeppesen R, Beas-Luna R, Crooks JA, Lorda J. Shifts in the distribution and abundance of coastal marine species along the eastern Pacific Ocean during marine heatwaves from 2013 to 2018. Marine Biodiv Rec. 2019;12:13.

Macdonald K. Molluscan faunas of Pacific coast saltmarshes and tidal creeks. Veliger. 1969a; 11:399-405.

Macdonald KB. Quantitative studies of saltmarsh mollusc faunas from the north American Pacific coast. Ecol Monogr. 1969b;39:33-60.

Macginitie GE. Ecological aspects of a California marine estuary. Am Midl Nat. 1935;16:629-765

Maia R, Rocha-Barreira C, Coutinho R. Reproductive cycle and embryonic development of the gastropod Melampus coffea (Linnaeus, 1758) (Ellobiidae) in the Brazilian northeast. Braz J Biol. 2012;72:935-43.

Mcgowan JA, Cayan DR, Dorman LM. Climate-ocean variability and ecosystem response in the Northeast Pacific. Science. 1998;281:210-7.

Mclean JH. Marine shells of Southern California, Natural History Museum of Los Angeles County, science series 24; 1978. Revised edition.

Morris R, Abbott D, Haderlie E. Intertidal invertebrates of California. Stanford: Stanford Univ Press; 1980

Nybakken J, Cailliet G, Broenkow W. Ecologic and hydrographic studies of Elkhorn Slough, Moss landing harbor and near coastal waters, July 1974 to June 1976 (chapter 5, the invertebrates of Elkhorn Slough). Moss Landing: Moss Landing Marine Laboratories; 1977. p. 162-80.

Oliver JS, Hammerstrom KK, Aiello IW, Oakden JA, Slattery PN, Kim SL. Benthic invertebrate communities in the peripheral wetlands of Elkhorn Slough ranging from very restricted to well-flushed by tides; 2009. SIMoN.

Page $\mathrm{H}$. Importance of vascular plant and algal production to macro-invertebrate consumers in a southern California salt marsh. Estuar Coast Shelf Sci. 1997:45: 823-34.

Pearcy W, Schoener A. Changes in the marine biota coincident with the $1982-$ 1983 El Niño in the northeastern subarctic Pacific Ocean. J Geophysic Res. 1987;92:14417-28.

Perry AL, Low PJ, Ellis JR, Reynolds JD. Climate change and distribution shifts in marine fishes. Science. 2005;308:1912-5.

Quinn WH, Neal VT, De Mayolo SEA. El Niño occurrences over the past four and a half centuries. J Geophysic Res. 1987;92:14449-61.

Russell-Hunter W, Apley ML, Hunter RD. Early life-history of Melampus and the significance of semilunar synchrony. Biol Bull. 1972;143:623-56.

Sanford E, Sones JL, García-Reyes M, Goddard JH, Largier JL. Widespread shifts in the coastal biota of northern California during the 2014-2016 marine heatwaves. Sci Rep. 2019:9:4216.

Smith AG, Gordon M. The marine mollusks and brachiopods of Monterey Bay, California and vicinity, the academy; 1948.

Whitcraft CR. Wetland plant influence on sediment ecosystem structure and trophic function (doctoral dissertation); 2007. Retrieved from https:// escholarship.org/uc/item/7jfof5mw.

Yamano H, Sugihara K, Nomura K. Rapid poleward range expansion of tropical reef corals in response to rising sea surface temperatures. Geophys Res Lett. 2011;38:4.

Yates L. Mollusca of Santa Barbara County. Santa Barbara Museum Nat Hist Bull. $1890 ; 1: 37-45$

\section{Publisher's Note}

Springer Nature remains neutral with regard to jurisdictional claims in published maps and institutional affiliations.

\section{Ready to submit your research? Choose BMC and benefit from:}

- fast, convenient online submission

- thorough peer review by experienced researchers in your field

- rapid publication on acceptance

- support for research data, including large and complex data types

- gold Open Access which fosters wider collaboration and increased citations

- maximum visibility for your research: over $100 \mathrm{M}$ website views per year

At BMC, research is always in progress.

Learn more biomedcentral.com/submissions 